Marquette University

e-Publications@Marquette

Social and Cultural Sciences Faculty Research and

Publications

Social and Cultural Sciences, Department of

$10-1-2001$

\title{
African American Single Full-Time Fathers: How Are They Doing?
}

Roberta Coles

Marquette University, roberta.coles@marquette.edu

Accepted version. Journal of African American Men, Vol. 6, No. 2 (Fall 2001): 63-82. DOI. (C) 2001 Springer. Used with permission. 


\title{
African American Single Full-Time Fathers: How Are They Doing?
}

\author{
Roberta L. Coles \\ Social and Cultural Sciences, Marquette University \\ Milwaukee, WI
}

Using a symbolic interactionist approach, interviews of 10 Black single full-time fathers indicate that these fathers perceive parenting to have had positive results for themselves. Specifically, the employment and income of most of the men had remained stable or improved. While their dating lives had suffered the most, they had sustained social activities with friends and families at a high level. Moreover, their assessments of their parent-child relationships and their own life satisfaction was positive.

As a focus of both public policy and academic research, fatherhood is increasingly garnering the attention of scholars, policy analysts and think tanks. However, most of the current interest focuses on understanding the procreative and parenting mindset of young single non-resident fathers, on enabling such fathers to increase their involvement, monetarily or personally, with their children, and essentially on transforming "absent" fathers into "responsible" fathers. This is particularly true if we are discussing black fathers.

The high rates of divorce and teen and non-marital births among African Americans as a group have led to the term "absent father" being nearly synonymous with black men (Dowd 1997). While the rate of teen pregnancy has been declining among African 
Americans in the last few years, the majority of black children nevertheless have been born to single mothers, who tend to have higher levels of poverty and lower levels of education than do single fathers or married two-parent families (Hall, Walker, and Acock 1995).

Encouragingly, a number of recent studies on so-called "absent" fathers have indicated that lack of marriage to the mother does not necessarily indicate non-involvement as a parent. For instance, Danziger and Radin (1990) and Wattenberg (1993) found that unwed minority teen dads are more involved than unwed white teen dads in their children's lives. Rivara, Sweeney, and Henderson (1986) found that the majority of single black teen fathers were living with the mother or having daily or weekly contact, which included feeding, playing, and diapering, with the mother and child. Lerman (1993) found that black unwed fathers were more likely to live close by and visit their children than were Hispanic and white fathers, and they had a higher frequency of paying child support (though the amount was less). Similar findings have been echoed in Seltzer (1991), Stier and Tienda (1993), and Taylor et al. (1990). In sum, while most studies of unmarried, particularly young, non-resident fathers have found declining involvement over time, many also found more involvement than expected (Larson et al. 1996, Mott 1990).

While these studies hint at the idea that black single fathers are doing more than media images might portray, they fail to address the fact that a small proportion of black single fathers parent full-time. That is, a small but noteworthy number choose to take on full parenting responsibilities. Eggebeen et al.'s 1996 study of National Survey of Families and Households (NSFH) data, which over-sampled black households, indicates that single-father families are increasingly formed by fathers who are young, have never been married, have low incomes and have fewer children. In each decade from 1960 to 1990, they found that nonwhite children were more likely than white children to reside in father-only families. Eggebeen et al.'s reading of census data indicated that by $1990,3.3$ percent of white children were in father-only families, while 5.6 percent of black children were. Census data from 1998 indicate that three percent of African American family households are male-headed with children, while two percent of white family households were male-headed with children. Despite the fact 
that father-only families are more common among black households, research has focused only on white father-only families (See, for instance, Greif 1982, 1983, 1985, 1990, 1995, DeMaris and Greif 1992, Greif and DeMaris 1989, 1990, 1995).

Hence, this paper stems from ongoing research exploring new territory in the emerging field of fatherhood. A preliminary study of 10 full-time single Black fathers was conducted to test the feasibility of a larger research project. Building upon the assumptions of "grounded theory" (Glaser \& Strauss 1967), no hypotheses were tested. Instead, it was assumed that knowledge--about the fathers' subjective parenting experiences, about needed adaptations in the empirical process, and about the theoretical direction of future research on African American fathers--would arise from the research process itself. While no theoretical questions were being tested in these preliminary interviews, the questions asked of respondents stemmed largely from a symbolic interactionist approach. Open-ended questions were designed to elicit the ways in which fathers defined fatherhood, enacted their roles, formed their expectations, interacted with others, found meaning for their own identity, and articulated how they were reshaped by the experience of full-time parenting. In culling those interviews, three aspects of fatherhood stood out: 1) the initial choice to parent was highly influenced by the desire to be the kind of father they didn't have, 2) fathers saw themselves primarily as providers and nurturers and least as authoritarian figures and disciplinarians, but their chosen roles were influenced somewhat by the gender of the custodial child, and 3) the level of satisfaction and self-assessment is generally high. This paper looks at the latter aspect. Specifically, I looked at 1) how fathers' employment and income were affected by parenting, 2) in what ways their social lives had changed, and 3) in what ways they perceived themselves to be changed by the experience and how they assessed their new identities as parents.

\section{Sample and Methodology}

This convenience sample of 10 fathers was recruited mostly in Milwaukee and Madison, Wisconsin, through word-of-mouth and through various local organizations, such as schools, neighborhood centers, parenting resource centers, and fatherhood projects; churches

Journal of African American Men, Vol 6, No. 2 (Fall 2001): pg. 63-82. DOI. This article is @ Springer and permission has been granted for this version to appear in e-Publications@Marquette. Springer does not grant permission for this article to be further copied/distributed or hosted elsewhere without the express permission from Springer. 
and Islamic centers; through related Internet websites; through the fathers themselves (snowball sampling); and by advertising in local alternative newspapers and radio stations. They are the first ten respondents in an ongoing qualitative study of African American single full-time fathers. Fathers first filled out a quantitative questionnaire that elicited demographic information about themselves and their children and addressed their family background, parenting style and philosophy, existence and proximity of support systems, distribution of household labor and childcare, and a limited number of measurable outcomes for child and father. Upon completion of the questionnaire, fathers participated in a two-to three-hour in-depth interview with the primary researcher or an assistant. Two of the interviews were conducted via the Internet, but the majority were conducted at a mutually agreed upon location, most often the home of the father. The interview included questions designed to explore the motivation and factors considered in choosing to parent full-time, definitions of and priority given to various parenting roles, satisfaction with choices made and changes in identity. Interviews of these ten men occurred from the end of 1999 through 2000.

While the sample is self-selected and too small to generalize from, the fathers in this sample had a number of characteristics in common. Nearly all the fathers were from the Midwest. Eight of these ten fathers resided in Wisconsin (either from the city of Milwaukee or Madison), one was from New Jersey and one was from Michigan (the latter two were contacted through the Internet). While their ages ranged from 22 to 43 years old at the time of the interview, the vast majority of the fathers were over 30 years old. Twenty percent of them were in their 20s, 40 percent were in their 30s, and another 40 percent were in their 40s. Ninety percent of the dads were at least majority age when their first child (not necessarily the custodial child) was born; 50 percent were in their 20s, and 20 percent were in their 30s.

As to education and income, 80 percent of them had at least some college and most of them would be considered middle class and/or in white-collar occupations. Specifically, two of them (20\%) had a high school diploma, two had some college, five had a college degree, and one had a master's. Twenty percent had incomes between 
$\$ 15,000$ and $\$ 24,999,60$ percent had incomes between $\$ 25,000$ and $\$ 34,999$, one had an income between $\$ 35,000$ and $\$ 49,999$, and one had an income over $\$ 50,000$. All of them were employed fulltime, as factory worker, plumber, state administrator, corporate manager, Air Force officer, elementary school teachers or social workers. Fifty percent of them held additional part-time employment, as sport coaches, building manager, taxi driver, or disc jockey.

Fathers are admitted to the study based upon their racial identity and custodial status. "Racial identity" is self-identified. Some fathers are biracial, but if they identified more with the African American heritage (as is often the case with biracial individuals), they were considered African-American for purposes of the study. "Custodial" is defined as the child residing with the father at least five days per week for most of the year. Custody may be formal, that is, legalized through the court, or informal, arranged by the parents or family without the courts' intervention. Custody may also follow a nonmarital birth, divorce, adoption, or widowhood.

In this case, three of the fathers (30\%) were divorced from the mother of the custodial child, and all of those fathers had immediately taken custody of the children. Six of the fathers (60\%) had never married the mother, 1 though most of the non-marital group had cohabited with the mother of the child for some period of time. Most of the never-married fathers had experienced a period of non-custody. One father had custody through adoption. None was a widower. About 50 percent of the fathers had legal custody--that is, custody adjudicated by the courts. The other 50 percent had made informal arrangements with the mother through mutual agreement that fathercustody would be best in their individual situations. Length of custody as a single father at the time of the interview ranged from 5 months to 12 years. Thirty percent of the fathers had custody less than a year. Forty percent had custody for two to four years, and 30 percent had custody for seven or more years.

The custodial children were diverse in regard to age, gender, and length of custody. There were thirteen custodial children altogether. Most of the fathers (70\%) had custody of all of their biological children, but three (30\%) had other biological children of 
whom they did not have custody. Seventy percent of the fathers had one custodial child, and thirty percent had two custodial children. The custodial children's ages ranged from one year to 16 years. Three (23 $\%)$ of the children were under the age of 5 , seven (54\%) were young school aged (6-12 years old) children, and three ( $23 \%)$ were teenagers. A slight majority (seven of the 13 ) of custodial children were female.

\section{Effects on Employment and Income}

As noted earlier, all of the fathers were employed at the time they took custody. Three of the six fathers who had not been resident continuously with the child since the child's birth used the nonresident period to finish college educations and obtain steady employment before taking custody. Hence, it seems likely that having full employment played a pivotal role in their willingness to become fulltime parents. However, this research was also interested in how parenting affected the fathers' employment, as research on single White fathers and on single mothers has indicated that single parents often feel their careers suffer from the added responsibilities.

Gasser \& Taylor (1976) and Orthner and Lewis (1979) found that single fathers commonly reported decreases in overtime and outof-town travel and increases in forgoing promotions. Likewise, Katz (1979) found his sample of single fathers putting in fewer hours, missing work, reducing travel, or going on flextime. Greif's surveys (1985and1990) of more than 1, 000 single fathers found dads more apt to have been fired or have quit and to have experienced jobrelated changes because of their child-care responsibilities. Greif also found that dads' earnings had declined, and they were not advancing.

In this study, fathers were asked about their type of employment and their income before and after custody. Open-ended questions asked how their parenting was impacting their employment in terms of income, absenteeism, type of occupation, job switches, etc., and what advantages and disadvantages their type of employment had for their parenting. Sixty percent (6) of the fathers had experienced an increase in their incomes since taking custody. Thirty percent (3) had experienced no change in their incomes.

Journal of African American Men, Vol 6, No. 2 (Fall 2001): pg. 63-82. DOI. This article is (C) Springer and permission has been granted for this version to appear in e-Publications@Marquette. Springer does not grant permission for this article to be further copied/distributed or hosted elsewhere without the express permission from Springer. 
However, two of those fathers had custody for less than a year, so it may be too early to detect any upward or downward effect on income. Only one of the fathers had experienced a salary reduction, when he moved from Denver, Colorado, to Madison, Wisconsin, in order to live in a city that was smaller and safer with good schools. Four of the fathers had quit jobs to take better ones, but none had been fired. One father who had experienced pay increases and was currently making more than $\$ 50,000$ a year, feared his parenting responsibilities were taking a toll on his career. Working at a large midwestern telecommunications corporation, he said,

I feel I cannot advance like I want to because of the pressures of corporate America--work more long hours and make constant overnight trips. Where I live now, I have no relatives to care for my children. But the advantage of my work is that I can almost leave the office when I need to. I just have to make sure I don't abuse that privilege.

Two other fathers also mentioned that they had to decline overtime or take off work for a sick child or take their child to work with them, but they saw that as an advantage rather than a liability. Larry, an elementary school teacher and father of 9-year-old Emily, said he was grateful for an excuse not to put in evening overtime. Alex, father of 1-year old Alex Jr., works nights at a manufacturing company. He says he doesn't put in as much overtime as he used to, but it affects his pocketbook more than his job. When he really needs to go in for extra hours, he has a mother and sister who will gladly watch his son.

A couple of the fathers can take their kids into work for an occasional few hours or day. Richard, a manager in a state agency and father of Tommy, says,

You know, the best work I do is when Tommy is at the office with me. And I think that the reason I do that is because I know that there are times I need him to be there, because of something that's happened at school or something like that. And I want him to be able to come into the office. And so, I get more work done when he is there because I want them to know that I am gonna get my work done if he is here, so that the next time there is another emergency, they won't have a problem with him coming.

Journal of African American Men, Vol 6, No. 2 (Fall 2001): pg. 63-82. DOI. This article is @ Springer and permission has been granted for this version to appear in e-Publications@Marquette. Springer does not grant permission for this article to be further copied/distributed or hosted elsewhere without the express permission from Springer. 
Overwhelmingly, the fathers' discourse indicated that parenting had actually benefited their educational attainment and employment stability, mostly by providing motivation to work and maintain jobs they ordinarily might have quit. Richard said, "[Parenting] changed my attitude about my work. Before, stuff that I considered just idiotic and outrageous in an office--I would have just told them ... you know, what they can do with their job, and I would have walked out. Now I tolerate a lot more, because I need the work. I need food for him."

Steve, who has custody of his 3-year-old daughter, is a counselor at a community center.

I was only a work-study student here when I took custody, and I had worked summer camps here. But after I got custody, I applied for a full-time position here and got it. It has motivated me to work harder in my job and education. Thinking back, I don't know how I did it when I first took custody. I was able to go to work, go to school and take care of her during the time that me and her mother split.

Ronald, a private elementary school teacher who has had custody of a daughter and son for about 10 years, likewise credited parenthood for his promotions. "I think if I hadn't had custody, I probably wouldn't have been promoted. I probably wouldn't have got my college degree. I probably wouldn't have did a whole lot of things that I did. The custody made me slow down and stop doing a lot of the foolish young people's stuff that I was doing."

Ray is father of 9-year-old Kyle. Ray only saw his own father twice in his life, as he died early living the "street life." Ray said, "[Parenting Kyle] has been a motivational force. I mean, even for me as a person, I've been more ... I guess I've got some of my dad in me. It's down in there, that part of me that just wants to ... I mean, I was real cavalier about life before I had Kyle. Like work. I could take it or leave it before, but now I work because I gotta."

Many of their reported benefits of full-time parenting-promotions, pay raises, educational gains, and other job improvements--may have occurred anyway, due to the passing of time 
and maturation. Most people, particularly married men, experience an increase in job status and salaries if they stay in the work force long enough. However, the findings here deviate to a degree from what other studies on single full-time fathers have found.

The effects here appear to be more positive relative to the reports found in most of the earlier studies on full-time dads. (One exception in the literature was Lerman and Sorensen 2000study on nonresident fathers. They found that an increase in father involvement with their children was associated with a subsequent increase in hours of work and earnings.)

There are several possible explanations for those differences. First, since black men tend to be more disadvantaged in the economic sector in terms of occupation and income, there is more room for improvement than there is for white single fathers. In addition, three of the eight fathers in white-collar jobs were teaching in elementary schools and two held social service jobs, neither of which is known for high salaries. However, both are known for their flexibility and one of the benefits of teaching is that the parents' yearly schedule is similar to that of their children.

Also, the fathers' reports of flexibility at their jobs may reflect workplace adaptations to the widespread societal-level changes in family structure that include a majority of dual-income married-couple families and an increasing number of single-parent families who need more flexibility in hours and location. Two of the men said that their supervisors were very sympathetic to finding ways to more easily balance work and family responsibilities. Richard, who adopted Tommy when he was 4 years old, said, "My supervisor has also adopted a child. He understands how things are going to be different when a child has been adopted, and some of the things you have to do when you have a young child. And so he has been very flexible with me." Steve, father of 3-year-old Jackie, explained, "I work at a community center and my boss is pretty cool. Everyone knows my situation. The director has kids. The office assistant has kids. This is a job that understands and promotes family values, whereas the big corporations might not. Here it is priority. If my daughter is sick, I can just go."

Journal of African American Men, Vol 6, No. 2 (Fall 2001): pg. 63-82. DOI. This article is @ Springer and permission has been granted for this version to appear in e-Publications@Marquette. Springer does not grant permission for this article to be further copied/distributed or hosted elsewhere without the express permission from Springer. 
NOT THE PUBLISHED VERSION; this is the author's final, peer-reviewed manuscript. The published version may be accessed by following the link in the citation at the bottom of the page.

Moreover, most of this sample, particularly those who had never been married or had very young children, lived within five miles of extended family members or the mother of the child, and could rely on them for child care when extra work hours or sick-day care was needed.

\section{Social Life}

Parents often complain that their social life suffers with the onset of children. What is probably more accurate is that their social life changes from isolated adult-oriented activities with other single and/or childless friends to more child-centered activities with married friends and/or friends with children. Often, their interaction with family members increases. Unlike married parents, however, single parents must also decide whether and how to incorporate dating into their families' lives.

In particular, studies of single custodial fathers, which have focused largely on divorced men, have found that many men switched from married friends to single friends, where they hoped they would find more support and pose less of a threat (Bartz and Witcher 1978, Barry 1979, Smith and Smith 1981). While some studies have found single fathers to have a more restricted social life (Greif 1990, Katz 1979), others (O'Brien 1987) found single fathers to have higher levels of socializing, particularly in terms of platonic female friendships, than married men.

In this research, fathers were asked how frequently they socialized with friends and family, and whether that was more or less than before custody. They were asked if and how frequently they dated and whether they desired to marry soon. Open-ended questions focused on what changes had occurred in their social lives, how dating was affected by custody, how their children and their dates reacted to one another, and what were the pros and cons of marrying.

As a group, the ten fathers had active social lives. Seventy percent of these fathers said they socialized with their friends at least weekly. Two said they socialized with friends two to three times a month and one said less than once a month. Nevertheless, seven of 
the fathers indicated that this was a drop from their pre-custody days, and three said there was no change in frequency. The three who said their social lives remained essentially unchanged were men who had not socialized much in the past.

As an adoptive father of Tommy, Richard's case is atypical in that he had time to deliberate his decision and prepare to take custody more than some of the other fathers did. Also, being gay, he did not have as many male friends with children as some of the other fathers did. He describes the decline in his social life:

A lot of the people who I would call my friends before Tommy dropped off after Tommy. I think it was they had nothing to identify with me. They didn't understand the experience of trying to get someone to go to bed by 7:30 p.m. You know? Or the idea that you are stuck at home at 7:30 p.m. But I tried to prepare myself for that beforehand. I realized that I wasn't going to be able to go out every night. (Before Tommy) I would go out with different friends three, four, five nights a week. Staying out late, getting up early and going to work. Guys in their 20s, that's what they do (laugh). So I started making myself go home, being home at 9 or at the latest 10 p.m. before I had Tommy. Or I would invite people over to the house, but I wouldn't go out. I wanted to adjust myself to that idea that I had to be home.

For most of the fathers, two main reasons for a drop or modification in socializing resonated in the interviews. First, a few of the men indicated that they had reduced time spent with friends who would not be good influences on their children or tried to maintain the social life by removing children from situations to which they don't want them exposed.

Steve said, "Certain friends I used to hang out with at school are not really responsible. They're my age and just out on the loose, maybe working, not in school, doing whatever. I hang out with them sometimes, but less."

Tracy described a recent Friday night:

Journal of African American Men, Vol 6, No. 2 (Fall 2001): pg. 63-82. DOI. This article is @ Springer and permission has been granted for this version to appear in e-Publications@Marquette. Springer does not grant permission for this article to be further copied/distributed or hosted elsewhere without the express permission from Springer. 
Last night family members came over and a lot of people came over. Train (his son's nickname) was here and his cousin Earl. I barbequed and made sure that they ate, and then I took them to Earl's for the night because I knew some people were going to start drinking. When I took this responsibility (of custody), I knew my life was going to change. So, I still see the same people, because none of my friends are into heavy drugs or anything like that. I have some that might use marijuana, but that's about it. And they would never do it in front of my child. So as long as they got the respect thing, they can come around.

Ronald, custodial father of two teenagers, said,

I don't know if I'm going to say I lost friends. The ones who were real friends I didn't lose. But I do feel like I had to change my ways, you know. I mean, I was more of a social partier and more of a ladies' man and all that kind of stuff. So I had to stop doing a whole lot of things in order to try to be a decent role model for my children.... I had to do things that were going to work for my family, not just for me.

A second, though less frequent, reason accounting for a reduction in socializing was due to relocation. Two fathers had moved from their home states to take different jobs, and one relocated to a military base. Those fathers said their social life and support system was drastically reduced. For one reason, they still needed time to establish new social networks, but also, unlike the other fathers, they lacked the proximity to extended family members who could watch their children while they maintained their social life.

Although two of the men in the study knew each other and had purposely chosen to live close to each other for support, two other fathers knew of other fathers with custody of children, but didn't make a point of socializing with them. None of the fathers were inclined to seek out other single custodial fathers for a support network. This finding was similar to earlier research on single fathers (Hanson 1988).

In terms of dating, earlier studies on single custodial fathers have had mixed conclusions. Greif's 1985survey of more than 1, 000 fathers found that 50 percent were dating weekly. The higher their income, the more likely they were dating. However, Greif's 1990 follow-up found that the fathers were dating less and enjoying their 
social life less. Similarly, Chang and Deinard (1982) and Katz (1979) said the general themes of their respondents were loneliness, lack of a social life, and restricted dating.

In this study, most of the men were not dating regularly. Two were not dating at all, and half were dating "irregularly." Of those who were dating with some regularity, one was dating monthly, another was dating once or twice a week, and one was almost daily. Eighty percent said they were not in a serious relationship, but 60 percent said they would like to marry soon. (One of the fathers actually has married since the interview. He was one of the few who said he didn't hope to marry soon, but he was also the one with the highest income.) At the time of the interviews, none of them were living with girlfriends, though three had cohabited with a girlfriend for a period of time during custody.

Several of the men complained that it was hard to find people who wanted to date a father who had custody of one or more children. Richard, the gay father, said

Just to go see a movie, it's hard getting a date. There are a lot of gay men around here who say, 'Oh, I'd love to have children some day. That would just be wonderful.' But when it comes to face the reality and the commitment issue, they can't deal with it. I tell people right up front that I have a son; if they don't want to be involved with that part of my life, then they really don't want to be involved here, so why hide it?

Richard's last sentence was echoed by a number of the fathers: "If you can't accept my child, you don't want me."

One of the heterosexual men said he found it was difficult to find women who wanted to be with a man with children. Don's experience was that "women without kids don't understand what it is like to be a parent, and women with grown kids have forgotten." However, most of the men who weren't dating regularly felt they just didn't have the time or opportunity, and when they did, they were leery about letting their dates have contact with their children, mostly for fear that the children would become attached. 
NOT THE PUBLISHED VERSION; this is the author's final, peer-reviewed manuscript. The published version may be accessed by following the link in the citation at the bottom of the page.

Steve said,

I just recently ended a long-term relationship. I decided that I don't date around my daughter. My daughter was very attached to my ex-girlfriend; she was calling her mom. And when I do date, it's not the first thing I bring up, but I tell them on the second or third date. Sometimes they are concerned about whether Julie's mom is "psycho, " worried that she might come after them. I assure them that she isn't.

Another father was hoping to find a woman who didn't want more children. Larry, a school teacher, has custody of Emily, but he also has a son whom he would like to have custody of eventually. He said,

I might be sounding selfish, but I'm hoping to find a woman who doesn't want any more kids. Because we can't afford it, unless she's going to make $\$ 100,000$. I don't want to bring no child where we've got to struggle and suffer. You know, I don't want the child to have to go through that.... mean, if she already has one or two kids, I would hope we could sit down and talk: Let's raise these together, as husband, wife and family. It's nice to share a child together, but we don't need another one. I've never been married, never been engaged, or nothing like that. I want it to be a one-time sort of deal. I don't want to go through divorce, all that kind of stuff.

Heterosexual Black men have a gender ratio in their favor, so finding a woman is not usually a problem. However, fathers may feel that a woman who already has children may complicate a future family situation, making adjustment more difficult and costly. On the other hand, fathers often feel that women who don't have children either don't understand their situation or desire to have more children whom the fathers think they cannot afford.

\section{Satisfaction with Parenting and Self}

Lastly, fathers were asked to assess how close they felt to their children and how satisfied they were with their parenting. Then they were given a list of 10 adjectives and asked to pick three that describe how they feel much of the time. The ten adjectives were isolated, misunderstood, incompetent, competent, uncertain, frustrated, happy, 
discriminated against, rewarded, and lonely. The qualitative questions asked them to explain why they picked those adjectives. In addition, they were also asked several questions that addressed how fatherhood contributed to their identity, what kind of reactions or feedback they received from other people, and how parenting had changed them.

Fathers were given a scale that ranged from very close, somewhat close, not so close, to distant to describe their relationships with their children. Because they were asked to respond for each child, there were 13 responses instead of 10 . Most of the fathers said they felt very close to their children. Three responses were in the somewhat close or not so close categories. Although none of the fathers felt distant from any of their children, there was a distinct gender difference in levels of satisfaction. All of the fathers who had sons only (four fathers with four sons) ranked their relationship as very close. Fathers of daughters only (three fathers with one daughter each and one father with two daughters) were split. The three fathers with one daughter ranked their relationships as very close (though two of those daughters are under 3 years old), and the one father who has two daughters ranked his relationship with them as "somewhat" close. Two fathers have a son and daughter each. One of those fathers said he was very close to both, but the other said he was very close to his son, but not so close to his daughter. In sum, all six sons had very close relationships with their fathers, and four of the seven daughters had very close relationships with their fathers. However, two of the seven daughters had somewhat close relationships, and one had a not-soclose relationship with her father.

A similar pattern appeared in the responses to the question asking fathers to rank their level of satisfaction with their parenting from very satisfied to dissatisfied. No father was dissatisfied with his parenting, but fathers were more satisfied with their ability to parent sons than daughters. Fathers were very satisfied with their parenting of four of the six sons, and they were somewhat satisfied with their parenting of the remaining two sons. However, fathers were very satisfied with their parenting of only two of the seven daughters. Instead, they were somewhat satisfied with their parenting of four daughters and not so satisfied with parenting of one daughter.

Journal of African American Men, Vol 6, No. 2 (Fall 2001): pg. 63-82. DOI. This article is (C) Springer and permission has been granted for this version to appear in e-Publications@Marquette. Springer does not grant permission for this article to be further copied/distributed or hosted elsewhere without the express permission from Springer. 
In regard to their perception of themselves, fathers had generally positive regard for themselves and their situation. Since each father was allowed to choose three, there were 30 responses. Twentythree of the responses were positive. The three most commonly chosen adjectives, all positive, were happy, rewarded, and competent. The negative adjectives that garnered a few votes were frustrated ( 3 responses), uncertain (2), lonely (1), and discriminated against (1). The frustration and uncertainty often were related to juggling the competing time demands of work, parenting, and personal needs and, particularly for the fathers of toddlers, learning their parenting skills on the go. "Discriminated against" was not related to race but rather to sexual orientation; one father is gay. Lonely was chosen by one of the men who was living away from family and friends, but a couple of the other men said if they could have chosen a fourth adjective, it would have been "lonely."

Once again, although the pattern was not as distinct as before, fathers of daughters tended to be slightly less positive and more negative in the adjectives they chose. They were less likely to choose "happy" and more likely to choose "frustrated."

Generally, past studies have found that single fathers tend to present themselves in a favorable light despite reports of loneliness and depression (Katz 1979). Most studies of single fathers have found that fathers perceive their relationships with their children as close (Atkins and Rubin 1976, Keshett and Rosenthal 1978, Orthner, Brown, and Ferguson 1976), and Ambert (1982) found single dads to be more satisfied with their parenting than single moms. Hanson (1988) and Orthner, Brown, and Ferguson (1976) found the majority of dads to rate themselves as competent. Even in Greif's 1990 follow-up survey, which generally found dads worse off on a number of aspects than they had been five years earlier, 80 percent of the fathers concluded that their parenting was "going well."

However, studies of the past did not focus on the extent to which these reports might be affected by the gender of the custodial child. In fact, most studies in the past have found that single dads are more likely to have custody of boys, whereas in this study girls are just slightly more common than boys ( 7 girls, 6 boys). Specifically, in 
Greif's 1985 survey of 1,136 single dads, 42 percent were raising sons only, 27 percent were raising daughters only, and 31 percent were raising both. Hanson's 1988 study found 57 percent of the fathers had custody of boys only, and 43 percent had custody of girls only. While the present sample is too small from which to generalize, 40 percent of the fathers had sons only, 40 percent had girls only, and 20 percent had both.

A few earlier studies looked at the outcomes for the children based on gender and same-sex custody. For instance, Santrock and Warshak (1979) found that father-custody boys were more socially competent than boys in two-parent families. By social competence, the researchers meant the boys scored higher on warmth, maturity, self-esteem, sociability, and depth. According to their study, father-custody girls scored lower on all of these measures. Guttman (1982) found a similar pattern; that is, that father-custody boys had better outcomes than father-custody girls. While the present study did not measure outcomes for children, one might speculate that fathers, as well as their children, might rank lower on outcomes when custody is crossgender.

Nevertheless, aside from the gender differences, the overall assessment of the effect of parenting on their lives was strikingly positive. Every single father thought that parenting had made him a better person. Some fathers pointed to very practical improvements, such as learning to wash dishes on a daily basis instead of leaving them dirty for weeks and buying new ones! However, most pointed to being more responsible--financially and socially. Richard, the adoptive father who worked in state government, said,

(Before I had Tommy) I had a good salary working for the Governor's office, but I was always tight on money. Just always tight. Like I say, I saw my parents once every two years. The first year that I had Tommy, in that first 12 months we took six round-trip flights, both of us, in one year. And I wanted to know where the hell did the money come from. How did we do that? You know, it still blows my mind that I did six round-trip tickets, and I could only manage to get one for one person every two years before that. You know? All for the same amount of money. Also, now I think about retirement. I never thought about that before Tommy. When I've done this job for 30 years,

Journal of African American Men, Vol 6, No. 2 (Fall 2001): pg. 63-82. DOI. This article is @ Springer and permission has been granted for this version to appear in e-Publications@Marquette. Springer does not grant permission for this article to be further copied/distributed or hosted elsewhere without the express permission from Springer 
and then stop and make my grandkids my new job. You know, being there for Tommy in a way that my parents can't be there for me because of their choices.

Alex, father of 1-year-old Alex, Jr., agreed. "Before I had him, I used to shop, shop, shop for things. Now I'm being more responsible, because I have to put a little money aside. Before I didn't do too much saving, because it was just me and I knew I had another check coming next week."

Other fathers indicated their children inspired them to persevere, to improve. Tracy, custodial father of Train and a new father of Tracy Jr., spent several years in a home for delinquent boys as an adolescent. He now works in a social service agency. He said,

These two guys, they are the reason I live, you know. Because I feel without them ain't no telling what I'd be doing. There's no telling, because I mean so much stuff, so much damage has been done to me, as far as an individual goes, you know. People using you and abusing you and all that. And I just think that if it weren't for those two, I probably wouldn't even be here myself. You know, I'd probably be in jail somewhere or probably dead, you know. So--they inspire me. But I'm just hanging strong because of those guys.... One is my heart, and one is my lungs.

John, a plumber, bought a house so he could have custody of 3-yearold Tonya. He said,

A lot of things changed when I became a father, especially a single parent. But it was change for the good. Because I would be doing other things that I probably shouldn't be doing if I didn't have a child. It put me in perspective. I was no longer living recklessly, so to say. I was thinking more into the future. I became a whole better person from having a child and being a single father. I'm more of an understanding person and a more thoughtful person as far as thinking about others.

Ronald, who acknowledges that parenting his teenaged daughter has caused him to experience depression for the first time in his life, nevertheless confirmed 
I don't look at parenting as having been a hindrance. I look at it as a motivational factor for me in my life, to accomplish things, to have more of a purpose in life, rather than look at it as something that's been slowing me down from reaching my own personal potential.... I think I got more into focus on what I had to do.... I mean, I feel like I've accomplished a lot. By doing it, it made me feel better about myself, as a person and as a parent.

These positive self-assessments may have also been aided by reactions they receive from others, which are, with one exception, largely affirmative. Most of the men reported receiving praise, commendation, and sometimes surprise or shock, from acquaintances and friends just for being a custodial parent. Most of them realize that much of this is due to their rarity in society, which makes them feel exceptional. In addition, several of the men indicated that their friends or family members had noted beneficial changes or outcomes as well. Tracy said that one of his friends told him that since he's had his sons, there's just a gleam in his eye. Ray was proud that his sister told him that she and her husband "think you are doing a fine job with Kyle." Steve said, "Being a father is a big part of my identity. If you ask my friends about me, who I am, I think many would say 'a good dad.' And that's good to me. That tells me I'm making good choices, being a good role model for my daughter, being consistent in what I say and do, and making sure our future is stable."

However, four of the men reported receiving comments to the effect of "How could the mom just leave them?" Tracy said such a question is an insult. "Because it is basically saying that she don't love her child, she just gave him to me, and I don't really want him either." Ray said he responds to this kind of statement by saying, "Well, she didn't leave her son, I mean, she can see him anytime she wants. And it's not like she just abandoned him on some wayside station. He is with his dad." The fathers are very aware that society doesn't expect men, particularly black men, to parent, at least not without some incentive at best, or coercion at worst.

\section{Conclusions}

While it is possible that the self-selected nature of the sample may account for the fathers' positive perspectives, overall the

Journal of African American Men, Vol 6, No. 2 (Fall 2001): pg. 63-82. DOI. This article is @ Springer and permission has been granted for this version to appear in e-Publications@Marquette. Springer does not grant permission for this article to be further copied/distributed or hosted elsewhere without the express permission from Springer. 
experience of these ten fathers suggest that parenting may likely have salutary effects for black dads. This seems to be most true in terms of stability of employment and motivation to improve one's lifestyle and status. We can't be sure such benefits stem only or even primarily from parenting, but it is clear that the fathers perceive this as so, which means that their parenting will be more highly valued. More research with a larger sample and comparing custodial, noncustodial, and perhaps single non-fathers would give us greater insight into the relationship between parenting and these various outcomes.

The most negative effect of parenting among single black fulltime fathers appears to be the reduction in social activity. While their social life, particularly in terms of dating, is more restricted, their social relations with friends and family was sustained at a high enough level to not detract from the overall satisfaction for most of the fathers. A number also indicated that some of the social reduction was due to the jettisoning of less constructive activity or social circles, which may explain why the reduction did not appear to severely decrease their satisfaction.

Personal and parental satisfaction did appear to be somewhat affected by gender of the custodial child. Men rearing daughters were less likely to rate their relationships as very close and their satisfaction as parents as very satisfied. They were slightly less happy and more frustrated than fathers rearing sons. If this 10 -father sample were representative, it would indicate that black fathers are more likely than white fathers to take on full parental responsibilities for daughters. If so, we might expect more black single fathers, on average, to feel less close to their children and less satisfied with parenting overall.

While I wouldn't want to conclude that full-time single parenting be the modus operandi for all single black fathers, it is clear that for this group of men, such a role was "a good thing." In a few cases, according to their own accounts, making and enacting the choice to parent may have rescued them from less auspicious alternatives. With increased attention to single fathers and the benefits of their experience, more non-resident fathers may perceive such involvement as feasible and promising.

Journal of African American Men, Vol 6, No. 2 (Fall 2001): pg. 63-82. DOI. This article is @ Springer and permission has been granted for this version to appear in e-Publications@Marquette. Springer does not grant permission for this article to be further copied/distributed or hosted elsewhere without the express permission from Springer. 
NOT THE PUBLISHED VERSION; this is the author's final, peer-reviewed manuscript. The published version may be accessed by following the link in the citation at the bottom of the page.

\section{Acknowledgements}

The author wishes to thank the men who generously gave of their time to participate in the research and the anonymous reviewers for their helpful comments. This research was funded by a Marquette University faculty grant and research fellowship.

\section{Notes}

1. This is just slightly different from U.S. Census figures (Cochran 1997) that estimate that 23 percent of Black custodial fathers are divorced and 54 percent are never-married.

\section{References}

Ambert, A. M. "Differences in children's behavior toward custodial mothers and custodial fathers." Journal of Marriage and the Family 44, no. 1 (1982): 73-86.

Atkins, E. L., Rubin, E. Part-time father. New York: Vanguard Press, 1976.

Barry, A. "A research project on successful single-parent families." American Journal of Family Therapy 7 (1979): 65-73.

Bartz, K. W., Witcher, W. C. "When father gets custody." Children Today 7, no. 5 (1978): 2-6.

Chang, P., Deinard, A. S. "Single-father caretakers: Demographic characteristics and adjustment processes." American Journal of Orthopsychiatry 52 (1982): 236-242.

Cochran, D. L. African American Fathers: A Decade Review of the Literature. Families in Society: The Journal of Contemporary Human Services. 78, no. 4 (1997): 340-350.

Danziger, S., Radin, N. "Absent does not equal uninvolved: Predictors of fathering in teen mother families." Journal of Marriage and the Family 52, no. 3 (1990): 636-642.

DeMaris, A., Grief, G. L. "The relationship between family structure and parent-child relationship problems in single father households." Journal of Divorce and Remarriage 18 (1992): 55-77.

Eggebeen, D. J., Snyder, A. R., Manning, W. D. "Children in single-father families in demographic perspective." Journal of Family Issues 17 (1996): 441-465.

Gasser, R. D., Taylor, C. M. "Role adjustment of single fathers with dependent children." Family Coordinator 25, no. 4 (1996): 397-401.

Glaser, B. G., Strauss, A. L. The discovery of grounded theory: Strategies for qualitative research. Chicago: Aldine Publishing Co, 1967.

Journal of African American Men, Vol 6, No. 2 (Fall 2001): pg. 63-82. DOI. This article is @ Springer and permission has been granted for this version to appear in e-Publications@Marquette. Springer does not grant permission for this article to be further copied/distributed or hosted elsewhere without the express permission from Springer. 
Greif, G. L. "Dads raising kids." Single Parent 25, no. 9 (1982): 17-25.

Greif, G. L. "Widowers." Single Parent 26, no. 7 (1983): 29-32.

Greif, G. L. "Children and housework in the single father family." Family Relations 34, no. 3 (1985): 353-357.

Greif, G. L. The Daddy Track and the Single Father. Lexington, MA: Lexington Books, 1990.

Greif, G. L. "Single fathers with custody following separation and divorce." Marriage and Family Review 20, no. 1-2 (1995): 213-231.

Greif, G. L., DeMaris, A. "Single custodial fathers in contested custody suits." Journal of Psychiatry and Law 17 (1989): 223-238.

Greif, G. L., DeMaris, A. "Single fathers with custody." Families in Society: The Journal of Contemporary Human Services. 71, 5 (1990): 259-266.

Greif, G. L., DeMaris, A. "Single fathers with custody: Do they change over time?" In Fatherhood: Contemporary Theory, Research, and Social Policy, ed. W. Marsiglio (Thousand Oaks, CA: Sage Publications), 193210.

Guttman, J. "The divorced father: A review of the issues and the research." Journal of Comparative Family Studies. XX, no. 2 (1982): 247-261.

Hall, L. D., Walker, A. J., Acock, A. C. Gender and family work in one-parent households. Journal of Marriage and the Family 57 (August 1995): 685-692.

Hanson, S., M. H. "Divorced fathers with custody." In Fatherhood Today: Men's Changing Role in the Family, eds. Phyllis Bronstein and Carolyn Pape Cowan (New York: John Wiley \& Sons, 1998), 166-194.

Katz, A. J. "Lone fathers: Perpectives and implications for family policy." Family Coordinator 28, no. 4 (1979): 521-527.

Keshet, H. F., Rosenthal, K. N. "Single-parent families: A new study." Children Today 7, no. 3 (1976): 13-17.

Larson, N. C., Hussey, J. M., Gillmore, M. R., Gilchrist, L. D. "What about Dad? Fathers of children born to school-age mothers." Families in Society: The Journal of Contemporary Human Services 77, no. 5 (1996): 279-289.

Lerman, R. I. Employment patterns of unwed fathers and public policy. In Young Unwed Fathers: Changing Roles and Emerging Policies, eds. I. R. Lerman and J. T. Ooms (Philadelphia, PA: Temple University Press, 1993), 316-334.

Lerman, R., Sorensen, E. "Father involvement with their nonmarital children: Patterns, determinants, and effects on their earnings." Marriage and Family Review 29, no. 2-3 (2000): 137-158.

Mott, F. L.. "When is a father really gone? Paternal-child conduct in fatherabsent homes." Demography 27, no. 4 (1990): 499-517.

Journal of African American Men, Vol 6, No. 2 (Fall 2001): pg. 63-82. DOI. This article is @ Springer and permission has been granted for this version to appear in e-Publications@Marquette. Springer does not grant permission for this article to be further copied/distributed or hosted elsewhere without the express permission from Springer. 
NOT THE PUBLISHED VERSION; this is the author's final, peer-reviewed manuscript. The published version may be accessed by following the link in the citation at the bottom of the page.

O'Brien, M. "Patterns of kinship and friendship among lone fathers." Reassessing Fatherhood: New observations on fathers and the modern family, eds. Lewis and O'Brien (London: Sage, 1987), 225-245.

Orthner, D., Lewis, K. "Evidence of single father competence in child rearing." Family Law Quarterly 8 (1979): 27-48.

Orthner, D., Brown, T., Ferguson, D. "Single-parent fatherhood: An emerging family life style." Family Coordinator 25, no. 4 (1976): 429-437.

Rivara, F., Sweeney, P., Henderson, B. Black teenage fathers: What happens when the child is born? Pediatrics 78 (1986): 151-158.

Santrock, J. W., Warshak, R. A. "Father custody and social development in boys and girls." Journal of Social Issues 35, no. 4 (1979): 112-125.

Seltzer, J. "Relationship between fathers and children who live apart: The father's role after separation." Journal of Marriage and the Family 53 (February 1991): 79-101.

Smith, R. M., Smith, C. W. "Child rearing and single-parent fathers." Family Relations 30, no. 3 (1981): 411-417.

Stiere, H., Tienda, M. "Are men marginal to the family? Insights from Chicago's inner city." Men, work and family, ed. J.C. Hood (Newbury Park, CA: Sage, 1993).

Taylor, R., Chatters, L., Tucker, M. B., Lewis, E. Developments in Research on Black Families: A decade review. Journal of Marriage and the Family 52 (November 1990): 993-1014.

Wattenberg, E. "Paternity actions and young fathers." Young Unwed fathers: Changing roles and emerging policies, eds. R. Lerman and T. Ooms (Philadelphia: Temple University Press, 1993), 213-234.

Journal of African American Men, Vol 6, No. 2 (Fall 2001): pg. 63-82. DOI. This article is @ Springer and permission has been granted for this version to appear in e-Publications@Marquette. Springer does not grant permission for this article to be further copied/distributed or hosted elsewhere without the express permission from Springer. 